\title{
First mover advantage on family firm succession
}

\section{Shital Jayantilal*}

Research on Economics, Management and Information Technologies (REMIT),

Univ Portucalense,

Portucalense Institute for Legal Research (IJP),

Rua Dr. António Bernardino Almeida, 541-619,

4200-072, Porto, Portugal

Email: shital@upt.pt

*Corresponding author

\section{Sílvia Ferreira Jorge}

\section{GOVCOPP,}

Department of Economics, Management, Industrial

Engineering and Tourism,

University of Aveiro,

Campus Universitário de Santiago,

3810-194 Aveiro, Portugal

Email: sjorge@ua.pt

\section{Tomás M. Bañegil Palacios}

Department of Business Administration and Sociology, Universidad of Extremadura,

Avda. de Elvas, s/n, 06006 Badajoz, Spain

Email: tbanegil@unex.es

\begin{abstract}
In spite of the proliferation of studies in various areas regarding the benefit of being first, the first mover advantage (FMA), in the context of family firms the work is (at best) scant. Adding to this, the impact that such firms have on the world economic stage it becomes both an interesting and a necessary research avenue. To study FMA in these firms, we will focus on one of the most critical stages in the lives of such firm: succession. As most of family firms do not outlive their founders, the passage of the executive power to the next generation is a crucial test that these firms face. It is not uncommon during this stage to see siblings rival to be nominated successor. This paper advances the succession game presented by Jayantilal et al. (2016), to study whether there is any advantage for the child who moves first in the succession race. The results indicate that indeed the first mover advantage exists, and that the emotional cost of conflict plays an important role in determining it.
\end{abstract}

Keywords: first mover advantage; FMA; sibling rivalry; family firm; succession; game theory. 
Reference to this paper should be made as follows: Jayantilal, S., Jorge, S.F. and Palacios, T.M.B. (2019) 'First mover advantage on family firm succession', Int. J. Applied Management Science, Vol. 11, No. 3, pp.243-254.

Biographical notes: Shital Jayantilal holds a PhD in Business Management and International Commerce. She coordinates the MPhil in Management at Univ. Portucalense (Portugal) and heads the research group of Strategy and Competitiveness in Research on Economics, Management, and Information Technologies (REMIT) investigation centre. She is a researcher and member of the Family Business Research and Training Centre (Cátedra da Empresa Familiar), having published in various international journals. Her main topics of research are family firms, game theory, strategy and experimental economics. She is an experienced consultant with more than 15 years of hands-on experience in aiding over 50 firms across diverse industries.

Sílvia Ferreira Jorge holds a $\mathrm{PhD}$ in Industrial Economics from the Nova School of Business and Economics and a degree in Economics from the Faculdade de Economia do Porto. She is an Assistant Professor in the Department of Economics, Management, Industrial Engineering and Tourism, of University of Aveiro. She lectures courses of microeconomics, industrial organisation and economics of information and uncertainty. A member of the research unit on Governance, Competitiveness and Public Policies (GOVCOPP), having published in various international journals, her main topics of research are industrial economics, game theory, microeconomics, economics of information and uncertainty, experimental economics and family firms.

Tomás M. Bañegil Palacios is a Full University Professor at Universidad de Extermadura (Spain), having headed the PHD program at that university. He is the Director of the Family Enterprise Department of that university. He has published various articles and books in diverse management areas. His main topics of research are family firms; innovation and entrepreneurship.

This paper is a revised and expanded version of a paper entitled 'Successor selection in family firms - advantage of being first' presented at Entrepreneurship and Family Enterprise Research Conference, Universidad de Extremadura, Spain, 5 September 2017.

\section{Introduction}

Family firms account for more than $70 \%$ of global annual GDP and are responsible for generating 50 to $80 \%$ employment worldwide (European Family Business, 2012). Asia is no exception, with family firms ranging from small mom and pop stores to large conglomerates. These latter account for more than half of the public listed companies representing more than a third of the region's market value (IFERA, 2003).

The uniqueness of all family firms reside, in what Habbershon and Williams (1999) referred to as familiness, resulting from the interconnection and overlap between the family and the firm. This permeability of the firm means that decisions made in the family firm are affected by both the business and the family dimension. Therefore, family firms are driven by both economic and noneconomic goals (Gómez-Mejía et al., 2001, 2007). Both financial values and emotional values contribute to the assessments and 
decision making in family firms, where the emotional values refers to the net benefits related to the family dimension. The fundamental emotional benefits relate to the continuity of the family firm in the hands of the family (i.e. legacy) and conflict is the key emotional cost (Chrisman et al., 2012; Zellweger and Astrachan, 2008). The relative importance which is attributed to the family or the business dimension, in the decision making process in family firms is dependent on many factors, but the cultural setting which envelopes the firm plays an essential role. Firms in collectivist societies, as is the case of the Asian countries, tend to subordinate the individual's interest for the common good of the group (Hofstede, 1994). Family firms in these settings tend to value the family serving role of the firm, ensuring that family harmony is not jeopardised, and firm intergenerational continuity is ensured (Sharma and Manikutty, 2005).

In fact, the passing of the firm's executive control is the most critical moment in the life of family firms, which enhances tensions both in the firm but also in the family. This is especially acute when siblings race for the successor position.

In recent times we have witnessed various public disputes, in the Asian business arena, involving siblings fighting to ensure they attain the control of the family firms. This was the case of the Ambani brothers, fighting to secure the successor position at Reliance Group, one of the largest Indian family conglomerates. Mukesh Ambani, the elder son of the founder, was appointed chairman but years of bitter fighting, both in the press and in the courts, severed the family ties and ended in the division of the group.

In South Korea, Lee Kun-hee, the chairman of electronic giant Samsung was sued by his brother and sister for the shares left by their late father. Taiwan's Eva Airways chairman Kuo-Wei was the successor was ousted, in March 2016, as a result of a dispute with his other three siblings, following the death of the family patriarch. These examples highlight the negative impact that siblings competing to succeed can have both in terms of disrupting family harmony but also by jeopardising the firm's sustainability. Family firms, given the overlap of the business and the family dimension, are prone to be a fertile ground for conflict and tension. This has triggered research on conflict in family firms and its impact on the firm's growth and continuity however little attention has been paid to the specific conflict resulting from sibling rivalry in the succession race. We respond to this by putting this type of conflict, which has plagued many Asian family firms, at the centre stage. We focus on studying whether there is any advantage for the sibling who places him/herself first in the succession race. In other words, we want to analyse if there is any first mover advantage (FMA). The FMA is the advantage that the initial (first-mover player) gets from being the first to play.

The wave of research on the advantages of being a first-mover is one of the most relevant areas of research in management but also other areas. Many sports have examples of strategic advantage for the first mover. To serve in tennis, home advantage in football and basketball are some of the most known FMA in sports.

The industrial economics literature has a majority of applications of this analysis where the mechanisms leading to FMA cover technological leadership [the first to bring a specific product or service to market enables FMA, see Spence (1981), Gilbert and Newbery (1982) and Reinganum (1983)], preemption of scarce resources [close relationship with suppliers may lead to few resources for potential rivals, see Prescott and Visscher (1977)], scale economies [the firm learning curve enables cost-efficiencies, see Schmalensee (1981)], switching costs [the high costs of switching to a rival product enable FMA, see Klemperer (1987)], among others. An industrial economics classic example of FMA is the Stackelberg (1934) oligopoly model (quantity leadership) ${ }^{1}$. 
Bargaining models also prove the existence of FMA (Rubinstein, 1982). Robinson et al. (1994) analyse the empirical evidence of FMA for pioneering markets (see also Scherer, 1994; Glazer, 1985). Applications of FMA flourished also in other setups including consumer marketing, climate policy (Pollitt et al., 2015), industry dynamics (Gomez et al., 2016), R\&D policy (Kopel and Löffler, 2008) and also managerial approaches [for an application and evolution of this literature, see Lieberman and Montgomery (1988, 1998)].

In spite of this proliferation of studies regarding FMA, in various areas, in the context of family firms the work is (at best) scant. Mathews and Blumentritt (2015) resorted to a sequential-move tournament game to model family firm succession. Their analysis identified the possibility of FMA yet their game, did not explicitly consider the emotional costs (related to the family dimension of the family firm) resulting from sibling competition. Whereas Blumentritt et al. (2013) mentioned the negative impact of the conflict which could erupt from competing siblings, their simultaneous move game did not explicitly consider the resulting emotional costs. In Michael-Tsabari and Weiss' (2013) succession game, conflict played a central role, however they focused on father/son conflict and not on the conflict resulting from competing siblings. More recently, Jayantilal et al. (2016) proposed a sequential game, of perfect and complete and information, which included, for the first time, the emotional cost that the children, and the family, incur when siblings compete for the successor position. In their paper they resorted to game theory to model the succession as a game, in which, the emotional costs resulting from sibling rivalry, are explicitly included. Their results showed that such costs have an impact of successor choice. In this paper, we advance their model to study whether or not there is any advantage for the child who moves first in the succession race.

\section{The model}

Following the Jayantilal et al. (2016) theoretical framework, the modelled game has three players: the father and founder of the family firm (F), his elder child (E) and his younger child (Y). The game starts by the elder child deciding whether to run for the CEO position in the family firm or instead pursue a career elsewhere, this is then followed by younger child's decision as to what to do and finally the founder selects his successor. The original game is represented in Figure 1.

The founder values his successor's ability to maximise the firm's performance, which is measured by the child's leadership skills $\left(\mathrm{L}_{\mathrm{i}}>0, \mathrm{i}=[\mathrm{E}, \mathrm{Y}]\right)$, encompassing all competencies, know-how and skills considered important (such as: managerial ability (Brockhaus, 2004); strategic thinking (Cater and Justis, 2009); accounting, HR and operational skills (DeNoble et al., 2007).

Given the unique nature of family firms, which arises from the overlap and interconnection of the business and family dimensions in the family firm, the founder also considers the child's family orientation $\left(\mathrm{O}_{\mathrm{i}}>0\right)$. He takes into account the extent the child perceives and values the family's involvement in the family firm (Lumpkin et al., 2008). Assuming both children have different ${ }^{2}$ endowments of leadership skills and of family orientation, the founder's preference for the business dimension, given by $\alpha$ $(\alpha>0)$ and the family dimension, given by $(\beta>0)$, will be determinate for the founder's choice. As a result, his payoff is a weighted sum of both the business and family related 
attributes of his successor. Founders who give more importance to the family serving role of the firm, known as family first type of founders, will tend to have higher values of $\alpha$, whereas those who attribute more importance to the business side will register higher values of $\beta$. The founder's preference will be determined by his values, education, and experience but also by the cultural context in which he is inserted. The Asian cultural context tends to be more collectivist, which will tend to reflect higher values of $\alpha$.

Figure 1 Game tree representation with elder being the first mover

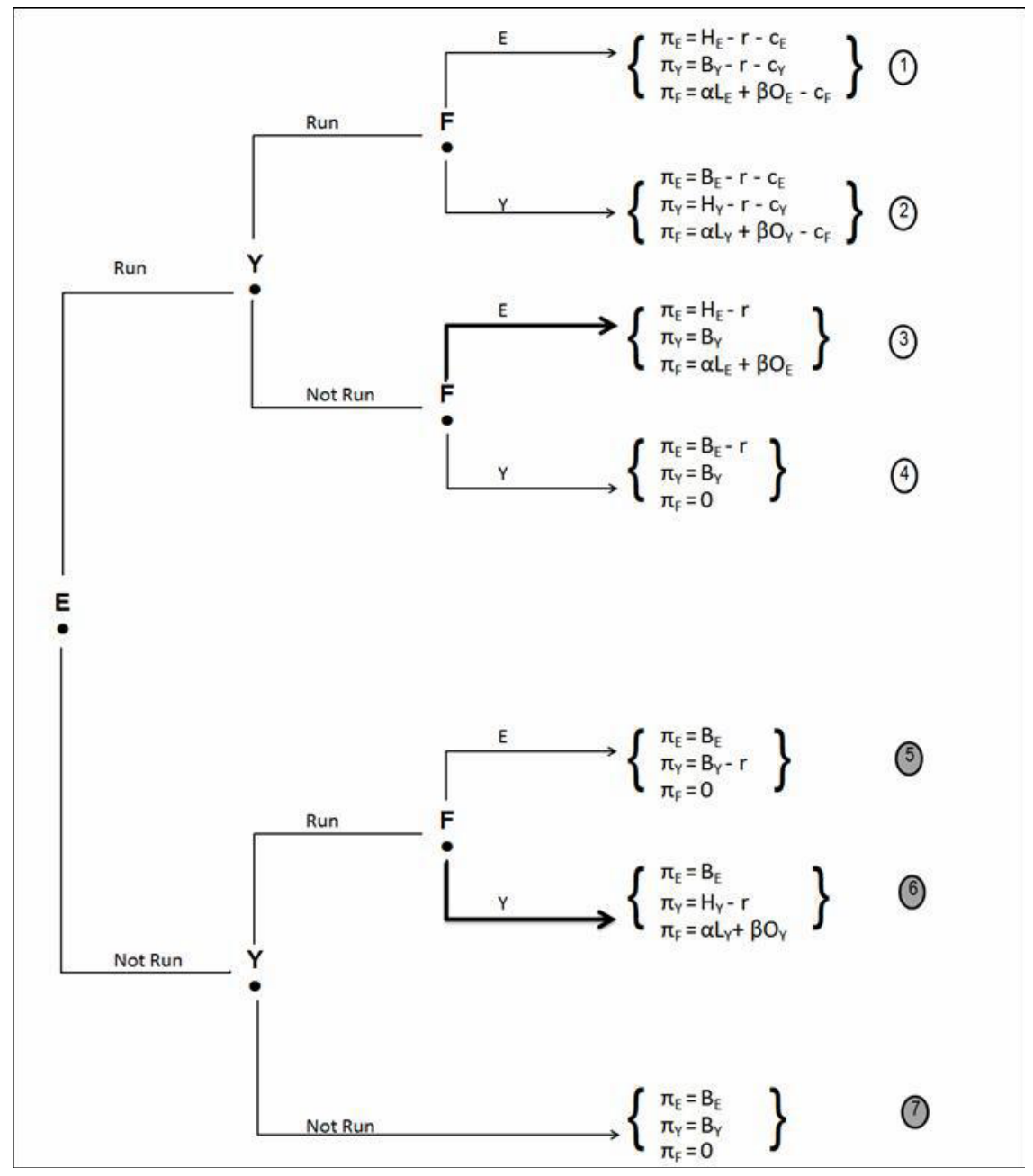

The founder's payoff results from the successor's attributes but is also negatively affected when his children compete to take his place, since conflict is an important emotional cost as witnessed in the previous examples of Asian family firms. This emotional cost of conflict is represented by $c_{j}\left(c_{j}>0, j=[E, Y, F]\right)$,). For the children, conflict is also an emotional cost, which they register in their payoff functions, too.

The children's payoff increases by the value they attribute to heading the family firm $\mathrm{H}_{\mathrm{i}}\left(\mathrm{H}_{\mathrm{i}}>0\right)$ net of the cost of running for the position, given by $\mathrm{r},(\mathrm{r}>0)^{3}$. We assume that 
the value they attribute surpasses the cost they may need to sustain to run for the position $\left(\mathrm{H}_{\mathrm{i}}>\mathrm{r}\right)$. Other than the family firm, the children can get a payoff, represented by $\mathrm{B}_{\mathrm{i}}\left(\mathrm{B}_{\mathrm{i}}>0\right)$, from pursuing a career outside (net of any costs incurred in securing such opportunity).

Each combination of actions results in different payoffs for all the players involved. These, seven paths, are numbered and presented on the far right side of the tree.

By employing backward induction the subgame perfect Nash equilibrium is reached and is illustrated in Figure 2.

Figure 2 Successor outcomes with elder moving first

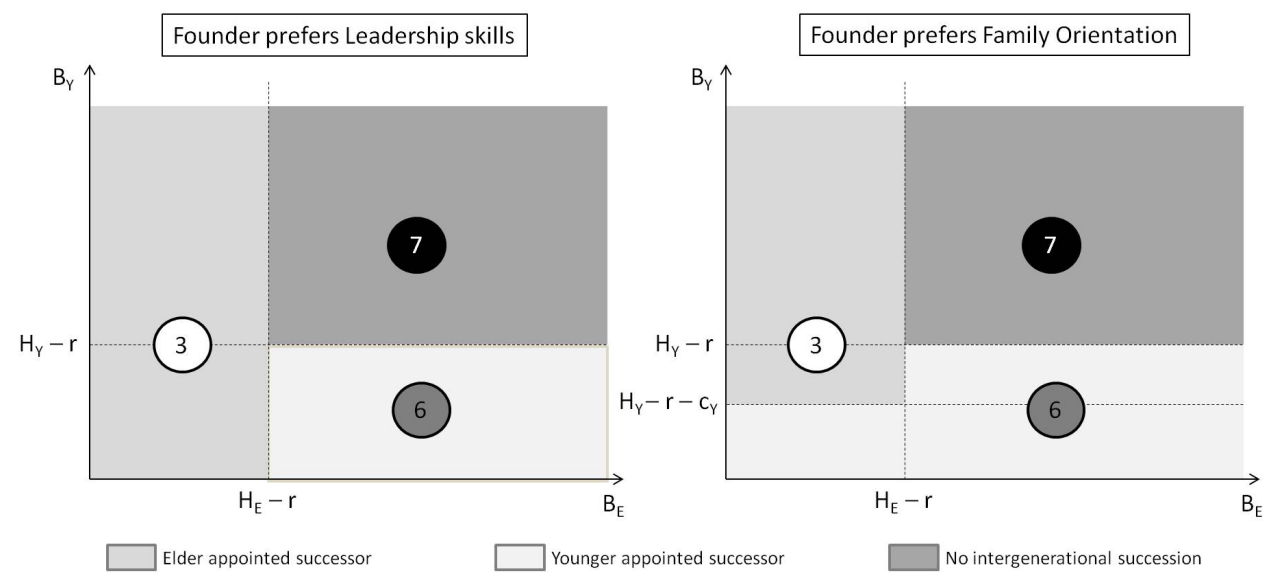

As expected, given that it is the founder who ultimately appoints the successor, his preference for leadership skills or family orientation is fundamental. A founder who values the business dimension, denoted by $\alpha\left(\mathrm{L}_{\mathrm{E}}-\mathrm{L}_{\mathrm{Y}}\right)$, more than the family dimension, denoted by $\beta\left(\mathrm{O}_{\mathrm{Y}}-\mathrm{O}_{\mathrm{E}}\right.$ ), will prefer $\mathrm{E}$ (given that $\mathrm{L}_{\mathrm{E}}>\mathrm{L}_{\mathrm{y}}$ and $\mathrm{O}_{\mathrm{Y}}>\mathrm{O}_{\mathrm{E}}$ ), and $\mathrm{E}$ will be appointed as long as he is available (i.e., $\mathrm{H}_{E}-r>B_{E}$ ). If $E$ is not available and $\mathrm{Y}$ is, then $\mathrm{Y}$ will be appointed (as it is assumed that the founder values intergenerational succession more than any other option).

In the opposite case scenario, that $\mathrm{F}$ relatively prefers family orientation to leadership skills (i.e., $\left.\beta\left(\mathrm{O}_{\mathrm{Y}}-\mathrm{O}_{\mathrm{E}}\right)>\alpha\left(\mathrm{L}_{\mathrm{E}}-\mathrm{L}_{\mathrm{Y}}\right)\right)$, then he will be opt for Y. Yet, in this case $\mathrm{Y}$ being appointed successor is dependent on the emotional cost he incurs in running against his sibling $\left(c_{Y}\right)$. The higher the level of reluctance of $\mathrm{Y}$ to conflict, the less willing he is to compete with his brother for the top position, and so $\mathrm{E}$ is more prone to be appointed successor.

When both children opt out of the family firm and decide to pursue their career elsewhere, then intergenerational succession will not be ensured.

\section{First mover advantage}

In the original game, the elder child moves first and the extent to which the younger child prefers to avoid conflict is directly linked to the elder child's propensity of being appointed successor. In fact, the emotional cost of conflict which the younger child incurs 
$\left(c_{Y}\right)$ is determinant in terms of successor outcome whereas the $c_{E}$ has no direct impact in terms of the definition of the new head of the family firm.

This raises the question regarding the possible advantage the child who moves first in the game has in being appointed successor. To analyse whether there is indeed any advantage for the first mover it is necessary to remodel our game changing the order of play and then comparing the results. In our original game the elder child moves first, who is then followed by the younger child and finally the founder chooses his successor. Altering the sequence and starting with the younger child as the first mover. Figure 3 presents the game tree for this case where the paths outcomes have similitudes with the previous game.

Figure 3 Game tree representation with younger being the first mover

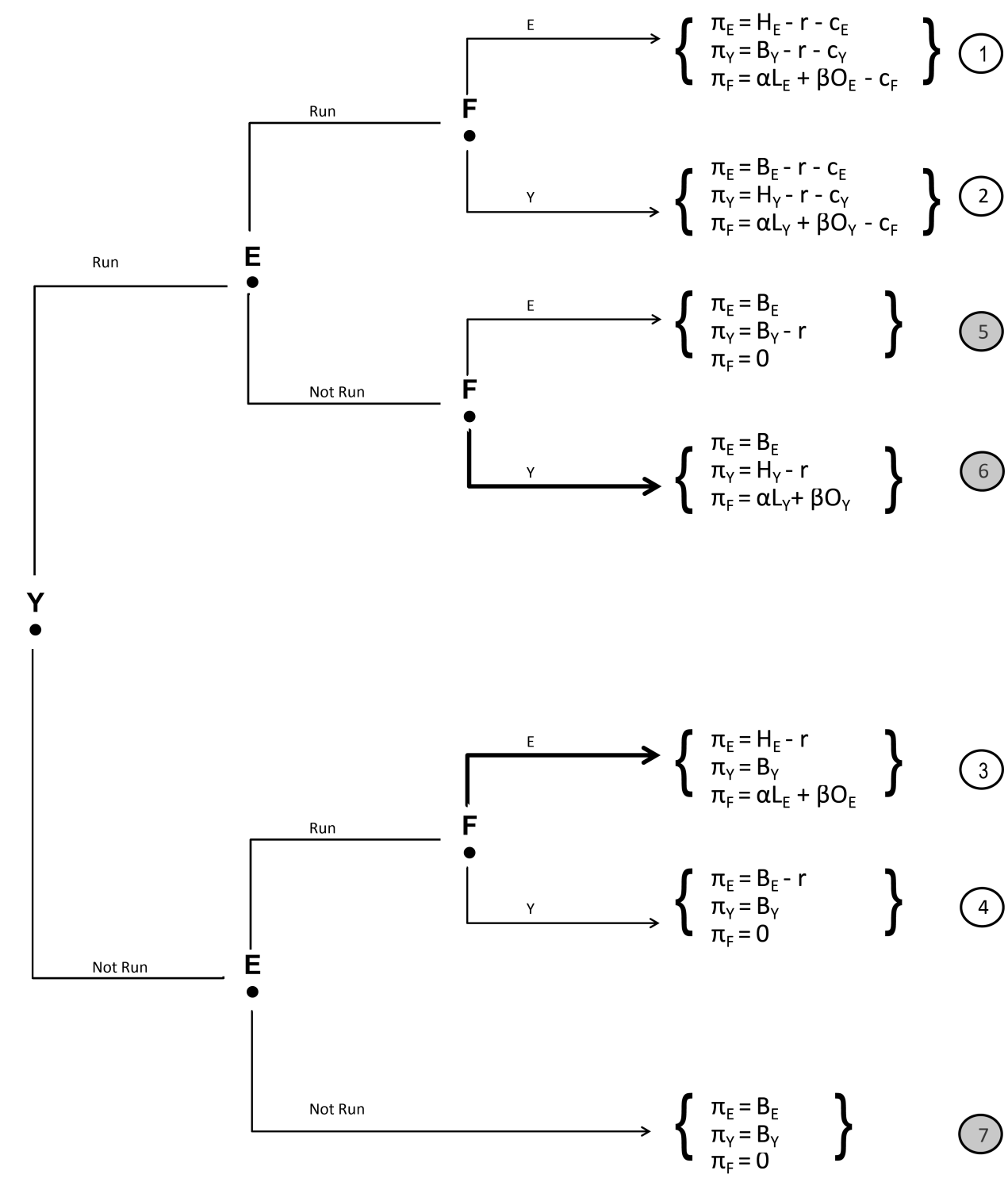


The younger child moves first and decides whether or not he wants to run for the successor position in the family firm. If he decides to run, the game moves to the upper part of tree, else it moves to the lower part. Then it is the elder child's move and he can either run or not run to become CEO of the family firm and finally the founder chooses his successor. At the far end of the tree are all the possible outcomes for this game for all the players resulting from the different paths.

Notice that the above payoffs are all the same as the ones obtained in the game where the elder child moves first (Figure 1) but result from different paths. For instance, the outcomes for path 5 in Figure 1, which results from the following sequence of decisions: $\mathrm{E}$ not run $/ \mathrm{Y}$ run $/ \mathrm{F}$ appoints $\mathrm{E}$, is the same as the outcome from path 5 in Figure 3, which results from the following sequence of decisions: $Y$ run/E not run/F appoints $E$.

To obtain the subgame perfect Nash equilibrium results for the game in which $Y$ moves first it is necessary to apply the same technique of backward induction as previously used. The successor outcomes are identified in Figure 4.

Figure 4 Successor outcomes with younger moving first

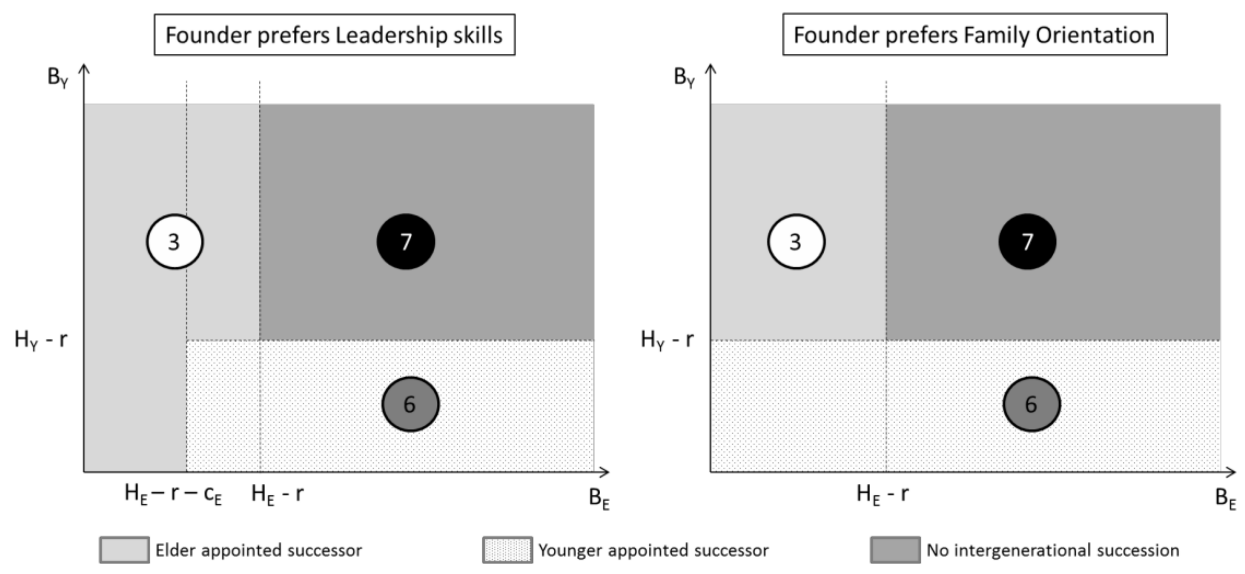

The subgame perfect Nash equilibrium results show that a founder who prefers family orientation to leadership skills will choose his younger child as successor as long as he is available $\left(\mathrm{H}_{\mathrm{Y}}-\mathrm{r}>\mathrm{B}_{\mathrm{Y}}\right)$ else he will opt for the elder one (if he is available). Conversely, a founder who values leadership skills more than family orientation will prefer his elder child to be his successor. In the case when E does not move first he incurs in the emotional cost of running against his sibling $\left(c_{E}\right)$ so he will only be available if $B_{E}<H_{E}-r$ $-c_{E}$. If both children value their career options outside the family firm more than heading the family firm, net of the cost of running, then intergenerational succession will not be secured. When both children are available it will be the founder's predisposition that will determine the successor outcome.

Figure 5 compares the successor outcomes for when E moves first with those resulting when Y moves first, by overlapping Figure 2 and 4. 
Figure 5 First mover advantage

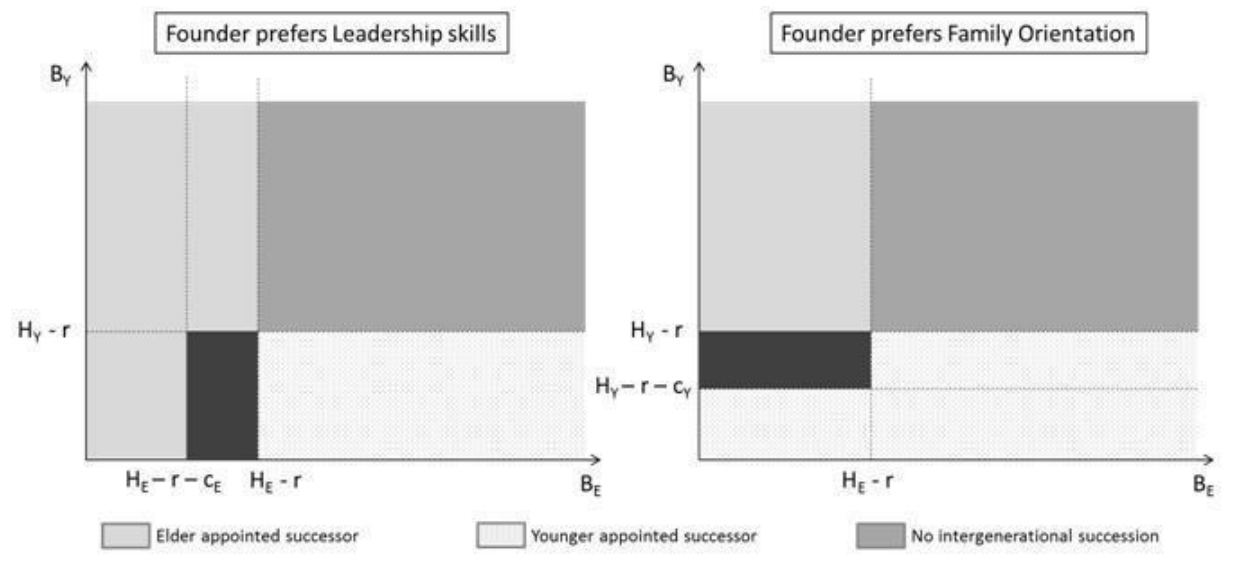

It is evident that the emotional cost of conflict which occurs when both children run for the successor position is more relevant, in terms of succession outcome, for the child who moves in second. Thus, there is a clear advantage for the first mover, which is illustrated by the darker shaded rectangles in Figure 5.

Consider, for example, a founder who prefers family orientation to leadership skills, then he is more inclined to choose his younger child as he is more family oriented than his elder child. However, the dark shaded rectangle shows that $\mathrm{E}$ has an increased propensity of being named successor instead of $\mathrm{Y}$, even when $\mathrm{F}$ would have preferred $\mathrm{Y}$, simply because E moved first.

The emotional factors justify the FMA. The cost of conflict is of fundamental importance. The higher the cost of conflict of the child who moves in second place, the larger the advantage the child who moves first has in being appointed successor. Consider, for example, a founder who is a business-first type, then the younger child has an increased possibility in becoming successor if he moves first, which is illustrated by the dark shaded rectangle in Figure 5. The dimension of this advantage is dependent on how much he values becoming successor, net of the cost of running, on one hand, and on the degree that the elder sibling wants to avoid conflict, on the other.

The emotional factors are of crucial importance in determining the first mover advantage. In more cohesive and collectivist family setting, members are more inclined to have higher affective attachment to the family firm and consequently, in such cases, the emotional factors will be more important than in other family contexts. For those types of families the FMA will tend to be higher than in other family settings.

The existence of the FMA means that from the children's perspective, the more reluctant a child is to conflict the greater will be the benefit for his sibling to move first. From the founder's perspective, he prefers that his desired successor be the first mover. Consequently, the founder has an added impetus to motivate his preferred successor to take the initiative and be the first to run for the top position in the family firm. 


\section{Conclusions}

Family firms play a crucial role in the Asian economic landscape. The family/business symbiosis is what is so unique in family firms. To fully understand the way decisions are made in such firms it is essential to consider, not only the economical, but also the emotional factors which stem from the overlap between the family and the business dimension. The passing over of the firm's executive power from the founder to the younger generation is a critical phase and the choice of the successor a fundamental issue. Too often, we have witnessed siblings rival for that position. This conflict is an important emotional cost, which jeopardises family harmony and can also put to risk the family firm's stability.

Furthermore, this paper brings to the forefront the study of FMA in family firm succession. Using game theory, the findings show that the emotional cost resulting from sibling conflict plays an important role in explaining the advantage for the child who moves first in the succession race. In fact, in more collective societies, as is characteristic of Asian cultures, the emotional cost will tend to be greater (than in other cultural settings), therefore the FMA will tend to be higher as the child is more reluctant to conflict, benefiting the sibling who moves first.

Future research can extend the FMA analysis to other succession processes such as second and third generation transfers, as well as including other potential successors (such as non family members).

\section{References}

Blumentritt, T., Mathews, T. and Marchisio, G. (2013) 'Game theory and family business succession: an introduction', Family Business Review, Vol. 26, No. 1, pp.51-67.

Brockhaus, R.H. (2004) 'Family business succession: suggestions for future research', Family Business Review, Vol. 17, No. 2, pp.165-177.

Cater, J.J. and Justis, R. (2009) 'The development of successors from followers to leaders in small family firms', Family Business Review, Vol. 22, No. 2, pp.109-124.

Chrisman, J.J., Chua, J.H., Pearson, A.W. and Barnett, T. (2012) 'Family involvement, family influence, and family-centered non-economic goals in small firms', Entrepreneurship Theory and Practice, Vol. 36, No. 2, pp.267-293.

DeNoble, A., Ehrlich, S. and Singh, G. (2007) 'Toward the development of a family business self-efficacy scale: a resource-based perspective', Family Business Review, Vol. 20, No. 2, pp.127-140.

European Family Business (2012) Family Business Statistics, Belgium.

Gilbert, R.J. and Newbery, D.M.G. (1982) 'Preemptive patenting and the persistence of monopoly', The American Economic Review, Vol. 72, No. 3, pp.514-526.

Glazer, A. (1985) 'The advantages of being first', American Economic Review, Vol. 75, No. 3, pp.473-480.

Gomez, J., Lanzolla, G. and Maicas, J.P. (2016) 'The role of industry dynamics in the persistence of first mover advantages', Long Range Planning, Vol. 49, No. 2, pp.265-281.

Gómez-Mejía, L.R., Haynes, K.T., Núñez-Nickel, M., Jacobson, K.J. and Moyano-Fuentes, J. (2007) 'Socioemotional wealth and business risks in family-controlled firms: Evidence from Spanish olive oil mills', Administrative Science Quarterly, Vol. 52, No. 1, pp.106-137.

Gómez-Mejía, L.R., Núñez-Nickel, M. and Guiterrez, I. (2001) 'The role of family ties in agency contracts', Academy of Management Journal, Vol. 44, No. 2, pp.81-95. 
Habbershon, T.G. and Williams, M. (1999) 'A resource-based framework for assessing the strategic advantage of family firms', Family Business Review, Vol. 12, No. 1, pp.1-25.

Hofstede, G. (1994) Culture's Consequences: Comparing Values, Behaviours, Institutions and Organizations Across Nations, Sage, California.

IFERA (2003) 'Family businesses dominate', Family Business Review, Vol. 16, No. 4, pp.235-240.

Jayantilal, S., Jorge, S.F. and Palacios, T.M.B. (2016) 'Effects of sibling competition on family firm succession: a game theory approach', Journal of Family Business Strategy, Vol. 7, No. 4, pp.260-268.

Klemperer, P. (1987) 'Markets with consumers switching costs', The Quarterly Journal of Economics, Vol. 102, No. 2, pp.375-394.

Kopel, M. and Löffler, C. (2008) 'Commitment, first-mover and second-mover advantages', Journal of Economics, Vol. 94, No. 2, pp.143-166.

Lieberman, M.B. and Montgomery, D.B. (1988) 'First-mover advantages', Strategic Management Journal, Vol. 9, No. 1, pp.41-58.

Lieberman, M.B. and Montgomery, D.B. (1998) 'First-mover (dis)advantages: retrospective and link with the resource-based view', Strategic Management Journal, Vol. 19, No. 12, pp.1111-1125.

Lumpkin, G.T., Martin, W. and Vaughn, M. (2008) 'Family orientation: individual-level influences on family firm outcomes', Family Business Review, Vol. 21, No. 2, pp.127-138.

Mathews, T. and Blumentritt, T. (2015) 'A sequential choice model of family business succession', Small Business Economics, Vol. 45, No. 1, pp.15-17.

Michael-Tsabari, N. and Weiss, D. (2013) 'Communication traps: applying game theory to succession in family firms', Family Business Review, Vol. 20, No. 10, pp.1-15.

Pollitt, H., Philip, S. and Klaassen, G. (2015) 'A model-based assessment of first-mover advantage and climate policy’, Environmental Economic Policy Studies, Vol. 17, No. 2, pp.299-312.

Prescott, E. and Visscher, M. (1977) 'Sequential location among firms with foresight', Bell Journal of Economics, Vol. 8, No. 2, pp.378-393.

Reinganum, J.F. (1983) 'Uncertain innovation and the persistence of monopoly', The American Economic Review, Vol. 73, No. 4, pp.741-748.

Robinson, W.T., Kalyanaram, G. and Urban, G.L. (1994) 'First-mover advantages from pioneering new markets: a survey of empirical evidence', Review of Industrial Organization, Vol. 9, No. 1, pp.1-23.

Rubinstein, A. (1982) 'Perfect equilibrium in a bargaining model', Econometrica, Vol. 50, No. 1, pp. 97-109.

Scherer, F.M. (1994) 'First-mover advantages from pioneering new markets: comment', Review of Industrial Organization, Vol. 9, No. 1, pp.173-176.

Schmalensee, R. (1981) 'Economics of scale and barriers to entry', Journal of Political Economy, Vol. 89, No. 6, pp.1228-1238.

Sharma, P. and Manikutty, S. (2005) 'Strategic divestments in family firms: role of family structure and community culture', Entrepreneurship Theory and Practice, Vol. 29, No. 3, pp.293-311.

Singh, N. and Vives, X. (1984) 'Price and quantity competition in a differentiated duopoly', RAND Journal of Economics, Vol. 15, No. 4, pp.546-554.

Spence, A.M. (1981) 'The learning curve and competition', Bell Journal of Economics, Vol. 12, No. 1, pp.49-70.

Stackelberg, H. (1934) Market form und Gleichgewicht, Springer-Verlag Wien New York.

Zellweger, T.M. and Astrachan, J H. (2008) 'On the emotional value of owning a firm', Family Business Review, Vol. 21, No. 4, pp.347-363. 


\section{Notes}

1 When firms produce homogeneous goods and choose production quantities, the leader (the firm that chooses quantity first) has higher profits than when both choose production quantities simultaneously. Notice that when firms set prices instead of production quantities, the FMA disappears (Singh \& Vives (1984) and Gal-Or (1985)).

2 If one child has both more leadership skills and more family orientation, he will be chosen as successor. It is only when both children are differently endowed that the founder must opt. We have maintained the assumption of Jayantilal et al. (2016) that $\mathrm{L}_{\mathrm{E}}>\mathrm{Ly}$ and $\mathrm{O}_{\mathrm{Y}}>\mathrm{O}_{\mathrm{E}}$.

3 Different costs of running for each child implies no significant differences on the conclusions but adds complexity in terms of results 